International Journal of Linguistics, Literature and Culture
Available online at https://sloap.org/journals/index.php/ijllc/
Vol. 5, No. 6, November 2019, pages: 60 67
$\begin{aligned} & \text { ISSN: 2455-8028 } \\ & \text { https://doi.org/10.21744/ijllc.v5n6.770 }\end{aligned}$

\title{
Lontar Digitalization on Lontar Study Center, Udayana University, Denpasar
}

I Made Sudarsana ${ }^{a}$

I Wayan Suka Yasa ${ }^{b}$

I Wayan Budi Utama ${ }^{c}$

\section{Article history:}

Received: 09 May 2019

Accepted: 31 July 2019

Published: 21 October 2019

\section{Keywords:}

balinese;

culture;

digitalization;

lontar;

tradition;

\begin{abstract}
The research aimed at knowing the reason of lontar digitalization. It was also to describe how lontar digitalization conducted and to explore how lontar digitalization implications towards Hinduism, Balinese culture, technology, economics, and law. The present study has a positive contribution to them. The findings of the current study tended a shift on digital lontar was celebrated according to conditions and utilization. Unlike the digital lontar were used in temples during Hindu holy days. Balinese cultural tradition of nyurat aksara will be reduced and there would be replaced by a digital machine namely, the indications and traditions would be lost related to literary traditions starting from the process of producing lontar leaves and powering of lontar. The tradition was replaced by digital technology. It will practically reduce the people who bring lontar replaced by gadgets, cell phones to read and businesses serve sales, for example, keropak, temutik, pengrupak in terms of the economy will be low.
\end{abstract}

2455-8028 ${ }^{\circledR}$ Copyright 2019. The Author. This is an open-access article under the CC BY-SA license (https://creativecommons.org/licenses/by-sa/4.0/) All rights reserved.

\section{Author correspondence:}

Sudarsana, I. M.

Universitas Hindu Indonesia, Denpasar, Indonesia

Tembau, J1. Sangalangit, Penatih, Kec. Denpasar Tim., Kota Denpasar, Bali 80238

Email address: sudarsana80@gmail.com

${ }^{a}$ Universitas Hindu Indonesia, Denpasar, Indonesia

${ }^{\mathrm{b}}$ Universitas Hindu Indonesia, Denpasar, Indonesia

${ }^{c}$ Universitas Hindu Indonesia, Denpasar, Indonesia 


\section{Introduction}

The problem faced on the lontar currently is rich in very valuable values. However, it was not handled properly. Many lontar have not been handled by digital processes or copied into computerization. They become damaged. Due to they are not stored properly. It happened because of the lack of facilities and infrastructure support as well as adequate and human resources quality in accordance with the time demands. Thus, the quality of the service provided to the community is also inadequate. Lontar is still stored in traditional ways. This resulted in lontar easily dirty and damaged. Another problem, the storage space did not meet the requirements. The list of lontar is still not in accordance with the lontar collection. There is no catalog meets the expectations. The conditions and problems are a common problem faced on the lontar in Bali (Yasa et al., 2018).

Based on the above description in the present study has formulated three problems. First, why the lontar study center of Udayana University in Denpasar digitize lontar?. Second, how is lontar digitalization conducted? Third, what the implications of lontar digitalization conducted toward Hinduism, Balinese culture, technology, economics, and law?

\section{Materials and Methods}

The theory of phenomenology, rational action and reception theory were used to answer the formulated questions. It was designed using a religious and cultural approach and qualitative descriptive methods. The implementation was conducted on lontar study center in Udayana University, Denpasar. Data were obtained from informants purposively chosen. It was collected by observation techniques, in-depth interviews, life-history, and documentation. Data were analyzed using qualitative descriptive techniques. The results are presented formally and informally.

\section{Results and Discussions}

In analyzing the arisen problems regarding the occurrence of lontar digitalization on lontar technical services unit of Udayana University Denpasar. The three theories are used namely, phenomenology theory, rational action theory, and reception theory. The three theories are used to answer the research questions.

Phenomenology was born as a positivistic methodological reaction. It departs from objective social facts on visible phenomena. The phenomenology theory is a reflection of Husser (1931), a philosophical idea is useful for understanding phenomena based on social interaction. The aim is to explore the deepest awareness of the individual. It is regarded the experience or event experienced and the way individuals interpret the experience called the consciousness stream (Wirawan, 2012; Haryanto, 2011)

Weber (2013), stated the rational action theory is related to conscious consideration and choice that the action was stated. It defines starting from choice existence are considered with human ratios then followed up with concrete actions. Weber (2004), distinguished human social actions, unlike instrumental rationality action (zwerk rational). This action is a social action conducted by someone based on conscious considerations and choices related to the action purpose and the availability of the tools used to achieve it. The intended consideration is to pursue rational interests, the use of technological sophistication to achieve goals, and the strategy existence to achieve goals.

Reception theory is used for conducting the lontar digitalization implication on the lontar technical services unit in Udayana University. Luxemburg (1984), distinguished between reception and interpretation. Reception is acceptance (reaction), directly and indirectly. Interpretation is more theoretical and systematic, including in literary criticism.

The based consideration on lontar digitalization at lontar study center of Udayana University in Denpasar to save and preservation. The major Balinese Hindu community is known as a devout and obedient who conducted religious teachings. All activities in various forms of life and cultural diversity are always based on the teachings of Hinduism. Therefore, it is known as a religious society. The concerns about the loss of lontar's, especially, old lontar from natural disasters, stolen, or not good in storage. The termites are eaten. The positive thinking to preserve lontar. In order to be saved, especially the old lontar, welcoming ideas with lontar digitalization (Suarta et al., 2018).

The ideological lontar digitalization is as a manuscript media contains guidance on ideological reflection. It is reflected in the noble behavior become the foundation of Balinese philosophy. There are also concepts of good and bad behavior. The concern is about the loss of lontar from natural and human factors form the basis of ideological

Sudarsana, I. M., Yasa, I. W. S., \& Utama, I. W. B. (2019). Lontar digitalization on lontar study center, Udayana University, Denpasar. International Journal of Linguistics, Literature and Culture, 5(6), 60-67. https://doi.org/10.21744/ijllc.v5n6.770 
considerations. In this case, there is ideologically to save lontar explains a state of truth, especially, the ideological power structure. Thus, people consider legitimate (Jirnaya, 2016).

The theological lontar digitalization on the belief that the lontar condition is maintained gives rise to various version reasons for digitalization. The meaning of the lontar is not lost. This is important due to the teachings of virtue, behavior, and life, as a form of manifestation that lontar is symbolic of religious knowledge. It means that it does not reduce the written meaning. Thus, it is easy to read. The physical lontar form is still intact or not damaged due to being taken or borrowed (Ginaya, 2018).

The consideration of the science and technology of lontar digitalization is important because lontar can be lost, both due to natural and human factors. First, the lost lontar because of theft or fire. Second, damage, for example, when lontar is often borrowed. There is used as research material by students who want to read lontar text. Third, the lontar is not treated properly by the owner. Fourth, there are several throws in the community may not be borrowed due to the community believes the lontar is sacred. The consideration of the use of lontar digitizing technology is an effort to save lontar, especially, lontar has been damaged, therefore, it is saved. It is also very helpful from the process of preserving lontar which is contained in literary works.

The economical considerations on lontar digitalization in terms of time, whenever the lontar is read, thus, it becomes the based guidance where and when the lontar needed is digital without coming to a place. Lontar digitalization is copied faster. The based legal considerations are the lontar study center at Udayana University in Denpasar are lontar digitalization. It proposes intellectual property rights on the behalf institution when it is important the results of digitalization get a patent. It means the lontar is protected.

The lontar digitalization program is conducted based on conscious and real. The consideration of the rational importance in the use of technological sophistication to achieve goals. It is also accompanied by strategies to achieve goals. The advances in technology can be useful to save the lontar. It has been damaged. Thus, useful literature can be saved.

The role of lontar digitalization is very positive for the steady and preservation of culture in the field of Balinese literature, especially, the national development of lontar preservation. Digitalization is one way of preservation due to the lontar comes from nature whose cannot be predicted. In fact, if the lontar treatment is good, there are lontar up to four hundred years old and there are more than that. If the process of making lontar is not good, it is likely the age of the manuscript will not last long. It is wherein the role of lontar digitalization to save the lontar from damage. Regarding the contents digitalization is maintained and can be copied again even if the physical lontar is damaged (Suastra, 2017).

The digitalization technique starts from the process of lontar manuscripts conservation defines cleaning up the lontar manuscripts. In this process, the lontar manuscript is cleaned, thus, it can be read. In the first process, namely cleaning the lontar, the letters of the lontar manuscript will be digitalized can be clearly seen. Please note, this process is conservation on the process of preserving, cleaning, and blackening the writing of the letters in the lontar using natural materials unlike citronella oil, alcohol 95\%, and hazelnut. Digitalization is preceded by a conservation process. Thus, the lontar are clearly visible.

The process of taking pictures is a process or method for producing images or photographs of an object by recording a light reflection on the object on light-sensitive media. The most popular tool to capture this light is the camera. Without light, no photo can be made. The types of camera used for taking lontar pictures. The Canon 24-105 camera is used on lontar study center for digital image transfer. As one of the world's best standard zoom lenses, the Canon EF 24-105 mm f/4L is capable of delivering sharp images. $600 \mathrm{D}$ cannon and two $6 \mathrm{D}$ cannon camera is for shooting according to the lontar physical lontar condition.

The image processing process using a background board and a computer or laptop device. The device has a high specification. It is used when processing images that have been set into a computer device. It has also been entered into digitalization that is conducted on lontar study center. The digitalization process of the photographs is edited and packaged into DVDs, VCDs, JPG, PDF.

Lontar digitalization implication is conducted on the lontar study center of Udayana University. The implications for Hinduism digitalization activities cause a shift in values. When the lontar is celebrated, it's sacredness remains. The term is called secular. When the lontar has been changed into digital form, the lontar does not need to be treated anymore. The term is called secularization. It is regarded lontar digitalization, it is maintained on meaning of the lontar authenticity is maintained. Therefore, the original lontar is not damaged. Lontar digitalization can be taken anywhere and can be read at any time not knowing the time and place.

Lontar value used as digitalization also conveyed by a millennial. People see a change due to lontar digitalization. In this case, in terms of the lontar content value or the contents do not change much. The values in the lontar become 
more developed, more accepted by the community, and more socialized. However, there is a change or shift from an ethical perspective. The ethics in question is the ethics of using lontar. When the lontar is made, of course, the inherent writer's characteristics, both in terms of the lontar contents and its use. It influences the lontar existence in terms of writing, art, rules written, and how to read it. Lontar in digital form will be easier to read anywhere and anytime. However, the treatment is different from the lontar from the old form has a standard in reading it. It defines in the form of digitalization becomes more practical, more efficient, wide-open access, which can be read and easily seen, as well as photos, pdf files, etc. They can be read anywhere and anytime. Having viewed on its form in the form of lontar leaves, they will be slowly opened, and are limited. Due to they are easily damaged. However, in digital form, besides being more durable and stronger, it can also be directly read (Darmawan \& Lembasono, 2015).

The implications for Balinese culture will soon be time for lontar digitalization. If it is learned to undergo ritual processes as before. They are not stored on a computer will not be valued as before, instead the Balinese have a flexible attitude. In order to save the lontar as cultural preservation requires an effort or a way namely, the lontar existence is not extinct. One way is lontar must be stored in a computer or digital media (cyberspace). Furthermore, the lontar essence as a manuscript of the old civilization must be preserved by the use of sophisticated technological devices (Budiasa et al., 2016).

The role of technology provides the development and role of lontar digitalization technology to produce new paragraphs as a concept to help spread the lontar culture as a storage medium and efforts to copy lontar. Digitalization can be studied and understood for the continuity of science, religion, and culture about lontar. The role of technology influences the lontar culture installation will be replaced by the role of technology. The device used is a kind of lempiran and pengrupak. Petal dynamics will be replaced by digital devices. Another problem appears in the lontar but the younger generation has an installation and is expected to internalize including clicking and being able to provide further benefits in the triumph object of protection, utilization, and lontar guidance. Having viewed the installation is a negative side. In this case, the role of human literacy is replaced by the role of technology.

Having seen this method is indeed traditional. The postmodern societies have begun to see small things through the role of technology. However, traditional society is no longer used traditional media to see modern media. Modern digital provides it's functions. Humans express salute to the high cultures, while the small things namely, the term comes from society, but it is seen with modern media today. That needs proof that humans must and want to learn lontar, but no longer need pengrupak and all kinds of stationery. However, digital photo is currently being used. They feel faster, more secure, and more accurate in their implementation despite the concern of what can build lontar as a good thing. It is the medium for humans present, whereas the ancients returned to the things are practiced. For example, lontar is currently traditional, but don't add more. The format is more interesting, but it is liked by everyone. Modern people's minds are good, but today's young generation is unable to respond, unlike things. In this case, there is no need to get your hopes up because the generation is up to date. There is no need to equate oneself to be able to understand culture as the previous generation because sometimes there are media only provide culture. However, the ways or tools used to learn it are difficult to understand. Thus, all generations must be able to complete or transform what is understood, something called zaman now (millenial).

The implications for the role of economics as the use of time or facilities help preserve culture. It can be learned and understood for the survival of posterity. The lontar study center team further stated that even socially the lontar score is more legal when used well. In terms of economical use of the benefits technology, it is easy to read. In this case, a person does not need to come to the lontar place. Thus, the economic aspect is from home can get a number of lontar that have been digitalized storage media through the network. This causes the people do not need to come directly means the visit to lontar will be reduced. Since everything is downloaded, there will be lost traditions related to the real tradition. For example, starting from the production of lontar "pepes niki ten wenten malih orang membuat lekesan lontar".

Based on the phenomenon occurred, in terms of economic practicality more often to bring digital media gadgets, rather than lontar. It is cool to bring gadgets than lontar everywhere and the modern economic lontar impression is carried everywhere. It is economically changed and has important benefits of lontar digitalization (Bint, 2015).

The implications for the law, in this case, the lontar study center of Udayana University in Denpasar provide patent protection resulting from lontar digitalization is beneficial for Balinese culture generally. Thus, it can be legally applied and disseminated for the benefit of science, religion, and culture through lontar digitalization. It invites the lontar owner as a cultural actor to register intellectual property rights. It was proven by the cooperation with Bangli Regency and seven subdistricts in Gianyar Regency.

Sudarsana, I. M., Yasa, I. W. S., \& Utama, I. W. B. (2019). Lontar digitalization on lontar study center, Udayana University, Denpasar. International Journal of Linguistics, Literature and Culture, 5(6), 60-67. https://doi.org/10.21744/ijllc.v5n6.770 


\section{Conclusion}

There are some conclusion can be drawn based on the above discussion.

(1) The reasons for lontar digitalization in the lontar study center of Udayana University in Denpasar are as follows.

(a) Lontar as a manuscript media is guidance of faith and ideological reflection from the past which contains noble teachings and becomes the foundation of Balinese philosophy. The lontar values are feared lost in modern times, both due to natural and human factors.

(b) Lontar digitalization is a form of cultural preservation to maintain the lontar condition in the community due to not being treated well. However, the lontar looks like the original. The purpose of lontar digitalization is not damaged. Due to it is often used, mainly read by students and borrowed as research material. Therefore, as it is a form of Balinese culture preservation.

(c) Digitalization technology is important to be conducted with the aim that when the lontar is lost due to natural factors and human factors. There are already copies stored in the media, either in the form of hard disks, CDs, flash disks, or stored in cyberspace. Thus, it will be quickly accessible and found a copy of it.

(d) Economic is the reason for lontar digitalization in terms of time. Lontar can be copied in a short time. Whenever the lontar can be read. Wherever there is a need for lontar. There is a digital presence without coming to a place to read the lontar.

(e) Digitalization is conducted on the based consideration that lontar is a cultural heritage. Thus, intellectual property must be protected in the role of lontar digitalization. Therefore, it is not used by irresponsible parties.

(2) Digitalization of lontar in the center of the study of lontar Udayana University in Denpasar, covers the following matters:

(a) Lontar manuscripts conservation namely, cleaning up of lontar manuscripts. Conservation is conducted, therefore, the lontar manuscript whose condition is damaged can be read. The first process is to clean up the lontar. Thus, the letters of the lontar manuscript will be digitalized will be clearly seen.

(b) Taking of lontar images or photographic. The process aims to produce a lontar image or an object by recording the light reflection on the object on light-sensitive media.

(c) Image processing is used in background boards and computer or laptop devices with high specifications. It has been set into the digitalization process taken are edited and packaged into DVD, VCD, JPG, and PDF.

(d) Lontar digitalization distortion in community houses namely, lighting problems occur because it is conducted in an open space. The damaged state of the lost lontar has contents. It is difficult to be sorted from the content per page and digitalization requires a long time in the process.

(e) Digitalization and lontar digitalization development show a quantitative increase but not consistently. It was stated thus before digitalization conducted conservation which affects the delay's digitalization.

(3) Lontar digitalization implication is conducted on the lontar study center of Udayana University in Denpasar.

(a) There is an assumption on lontar digitalization has implications for shifting values of Hinduism namely, lontar change from sacred to profane. In this case, it is after being made a digital form.

(b) The belief on lontar digitalization remains sacred even though it has been converted into digital form. It is based on how to use lontar digitalization and how to understand lontar digitalization more deeply.

(c) Lontar digitalization has implications for millennials namely, interest in the lontar from how to access and ease of learning the lontar.

(d) The implication for Balinese culture as preservation is based on the tendency of the community to preserve the values of lontar culture in the past, besides, as well as a form of preservation to preserve lontar art as a culture passed on to grandchildren.

(e) Implications for technology give rise to the role of lontar digitalization technology to produce new paragraphs as a concept of helping spread the culture of lontar by digitalizing through technology. The purpose is to be able to be learned and understood for the continuity of knowledge about lontar.

(f) In terms of economics is the general public from home can get many lontar has been digitalized. Doing inhome is accessing or disseminated through storage media. Copying lontar via digital media is faster.

(g) Lontar study center provides patent protection resulting from lontar digitalization. It can be beneficial for Balinese culture generally. It is legally and it can be applied and disseminated for the benefit of science. 
Conflict of interest statement and funding sources

The authors declared that they have no competing interest.

Statement of authorship

The authors have a responsibility for the conception and design of the study. The authors have approved the final article.

Acknowledgments

The authors would like to thank the editor of IJLLC for their support, advice, and valuable time.

Sudarsana, I. M., Yasa, I. W. S., \& Utama, I. W. B. (2019). Lontar digitalization on lontar study center, Udayana University, Denpasar. International Journal of Linguistics, Literature and Culture, 5(6), 60-67. https://doi.org/10.21744/ijllc.v5n6.770 


\section{References}

Bint, K. A. S. (2015). Dekonstruksi sastra lontar di era globalisasi (perspektif kajian budaya) (Doctoral dissertation, Universitas Gadjah Mada).

Budiasa, K., Ari, I. P., \& Gunarti, E. (2016). Genealogical Information Searches in Kawitan Culture on Balinese Hinduism Society: from Lontar (palm-leaf manuscript) to Electronic form.

Darmawan, R., \& Lembasono, D. (2015). A tale on a leaf: promoting indonesian literature and culture through the development of the lontar digital library. In Digital Heritage and Culture: Strategy and Implementation (pp. 163175). https://doi.org/10.1142/9789814522984_0012

Ginaya, G. (2018). The Balinese calendar system: From its epistemological perspective to axiological practices. International Journal of Linguistics, Literature and Culture, 4(3), 24-37.

Haryanto, S. (2011). Sosiologi ekonomi. Yogyakarta: Ar-ruz Media.

Husser, E. (1931). Ideas.

Jirnaya, I. K. (2016). Lontar roga sanghara bhumi: ritual referention for natural balancing in Bali. International Research Journal of Management, IT and Social Sciences, 3(7), 1-8.

Luxemburg, L. A. (1984). On universal infinite-dimensional spaces. Fund. Math, 122, 129-147.

Suarta, I. M., Widana, I. W., \& Citrawan, I. W. (2018). Lontar manuscript readability. International Journal of Linguistics, Literature and Culture, 4(2), 58-65.

Suastra, I. W. (2017). Balinese local wisdom and their implications in science education at school. International Research Journal of Management, IT and Social Sciences, 4(2), 48-57.

Weber, M. (2004). The essential Weber: a reader. Psychology Press.

Weber, M. (2013). From Max Weber: essays in sociology. Routledge.

Wirawan, D. I. (2012). Teori-teori Sosial dalam Tiga Paradigma: fakta sosial, definisi sosial, dan perilaku sosial. Kencana.

Yasa, I. P. P., Duija, I. N., \& Wastawa, I. W. (2018). The Role Of Lontar Digitalization For Hinduism Informal Education In Preserving Cultural And Hinduism At The Puri Gede Kerambitan Tabanan. Vidyottama Sanatana: International Journal of Hindu Science and Religious Studies,2(2), 282-286. http://dx.doi.org/10.25078/ijhsrs.v2i2.630 


\section{Biography of Authors}

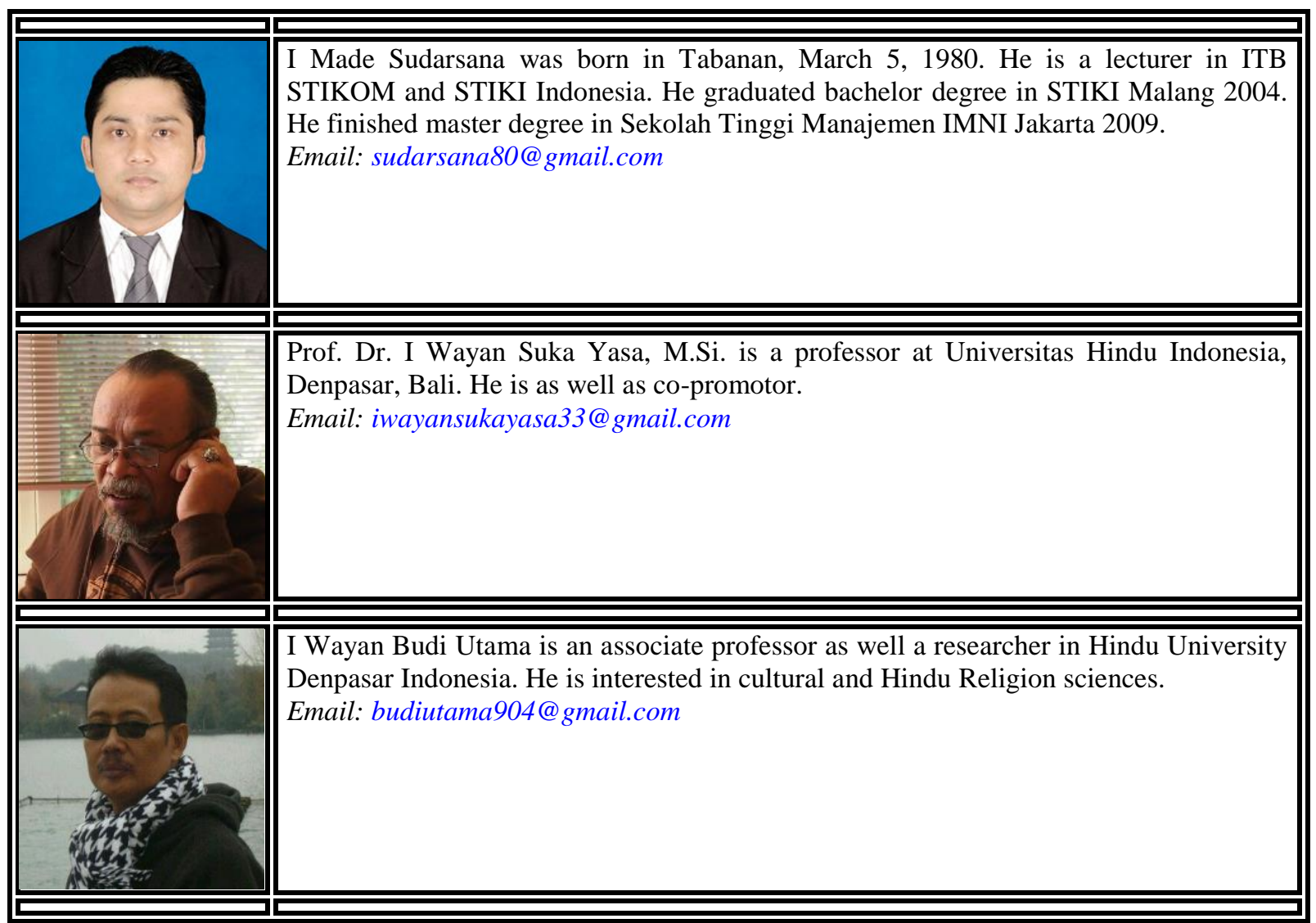

Sudarsana, I. M., Yasa, I. W. S., \& Utama, I. W. B. (2019). Lontar digitalization on lontar study center, Udayana University, Denpasar. International Journal of Linguistics, Literature and Culture, 5(6), 60-67. https://doi.org/10.21744/ijllc.v5n6.770 